\title{
The Influence of Motivation and Work Discipline on School Teacher Performance
}

\author{
Helisia Margahana ${ }^{1}$, Garaika ${ }^{2}$ \\ ${ }^{1,2}$ Sekolah Tinggi Ilmu ekonomi Trisna Negara
}

\begin{abstract}
The Influence of Motivation and Work Discipline on the Performance of Primary School Teachers in the Ogan Komering East Ulu Region, the purpose of this study was to determine the effect of motivation and discipline on teacher performance either partially or simultaneously. This study's object was the primary school teachers in the Ogan Komering Ulu Timur region, with a total sample of 83 teachers. This study's data analysis technique is the analysis using multiple linear regression analysis and classical assumption test. Based on the research results, motivation and discipline have a partial or simultaneous influence on teacher performance, and the results of the regression analysis show $\mathrm{Y}=7.805+0.246 \mathrm{X} 1+0.213 \mathrm{X} 2+\mathrm{e}$. In contrast, the correlation coefficient value shows a strong enough effect between motivation and discipline variables with variables. Teacher performance. This can be seen from the interpretation at $0.40-0.60$. And the test of determination of the rsquare value is 0.188 . This means that the motivation and discipline variables affect the employee work productivity variable by $18.8 \%$, while $(100-18.8)=81.2 \%$ teacher performance variables. They are influenced by other variables, such as compensation and leadership.
\end{abstract}

Keywords: Motivation, Discipline, Performance

\section{Introduction}

Teachers are educators and teachers in early childhood education through school or formal education, primary education, and middle education. Teachers like this must have some legal qualifications (Markus \& Kitayama, 2014). In a broader definition, anyone who teaches something new can also be considered a teacher. Formally, a teacher is a teacher at a public or private school based on a formal education background of at least a bachelor's degree and has legal provisions as a teacher based on the applicable teacher and lecturer laws in Indonesia. One of the government's efforts to support the implementation of this law is by increasing teacher education qualifications through an equalization program(Okello \& Gilson, 2015).

These efforts are still complemented by various training and upgrading and teacher certification, which began in 2008. These efforts indicate that teacher performance needs to be improved. Teacher performance can be seen from the work process or work results. A job always has work steps (procedures). Work procedures always lead to an increase in the yield of that work following the demands of work. If a job is done accordingly with the process, it will arrive at the desired results. The benchmark of performance is a demanding job that describes the work that it wants to achieve. How far someone can do the job is then compared with the results achieved is named one's performance on the job (Cui et al., 2013). Someone who is a teacher should have high performance have a positive attitude towards work at hand, attitude, like work earnestly, take care quality of work, responsible, dedicated high, etc. Because it's such an essential teacher performance factors in their role to increase success education, then keep and strive for teachers to have the absolute high performance required (Gregory \& Fergus, 2017). What factors affect improving teacher performance needs to be sought immediately answer to problem enhance the quality of education immediately can materialize. The teacher is the primary key to enhancing education quality because the essential requirement for realizing that education quality is if the educators' professionalism carries out its 
implementation can depend. The world of education will not experience any changes as long as the lecturers and teachers do not want to change and are not adaptive and anticipatory to change (Baumann \& Krskova, 2016).

One of the essential indicators regarding our education today is the low quality of teachers for all levels of education (Gregory et al., 2016). that the low quality of education will always be related to the low quality of teachers. The condition of our instruction is at a meritocratic and conservative level towards change. This can be seen from several aspects, especially the quality of school principals' quality and leadership, which is less transparent. Yet concerning efforts to improve human resources quality, this must be addressed immediately (Skaalvik \& Skaalvik, 2017).

For this reason, this study will relate to how much influence the management and leadership of the principal on teacher performance. Another effort made by the government is to reorient education management, namely from a center-based quality improvement management system to school-based quality improvement management (Skaalvik \& Skaalvik, 2017). The essence of school-based quality improvement management is school management autonomy and participatory decision making to achieve school quality objectives. Through this system, school managers or managers are given the authority to regulate and improve the educational process according to their initiative, thereby reducing dependence on the central government. The definition above shows that schools have greater control to manage their schools because Schools know more about their strengths, weaknesses, opportunities, and threats to optimize the use of available resources to advance their schools(McMillan et al., 2011).

In its implementation, it requires changes in attitudes and behavior of all school components, including principals, teachers and administrative staff, including parents and the community in seeing, understanding and helping at the same time as monitors who carry out monitoring and evaluation in school implementation(Wood, 2018). Changes in attitudes and behavior will occur if existing school resources are utilized and managed optimally and effectively by the school principal as the person responsible for implementing school education. The demand for principals who have strong management and leadership abilities is, in fact, inseparable from issues of educational praxis and issues related to educational decentralization, namely: The problems that often arise include; limited authority of school principals, which implies the low effectiveness of achieving academic targets in schools. This issue also concerns the lack of control given to the principals in developing educational management in schools, including the limited space for movement in utilizing educational resources allocated to schools (Lusk et al., 2005). In matters of independence and creativity, the management of education in schools is very dependent on the reliability of a school principal, where the principal has greater authority to make decisions related to school management policies than the education management system managed by the central government. Meanwhile, in terms of openness and accountability of school management, the principal, as the manager in organizing and managing his school, should pay attention to school management inputs. The management inputs referred to include: straightforward tasks, detailed and systematic plans, programs that support the implementation of school members to take action, and the existence of an effective and efficient quality control system to ensure that the agreed goals can be achieved (Baumann \& Krskova, 2016).

Motivation is the drive, effort, and desire in humans that activate, empower, and direct behavior to carry out tasks well within their work scope. The reason is a process that helps determine the intensity, direction, and 
persistence of individuals to achieve goals. Motivation is a process that starts from strength in physiological and psychological terms or needs that result in behavior or encouragement aimed at a goal or incentive (Kurniawan, Harry, 2019). The effect of work motivation on performance shows that the relationship between cause and teacher performance indicates a positive and significant relationship(Allen et al., 2002).

According to discipline, it is ideal for supporting the implementation of tasks according to the rules to support work optimization. One of the requirements so that that discipline can be fostered in the work environment is a complete division of labor to the lowest employees or officers, so that everyone knows consciously what their duties are, how to do them, when the work starts and is finished, what kind of work is required, and to whom is accountable for the results of the work (Schmitter et al., 2020). For this reason, discipline must be cultivated so that order and evasion will also grow. Without a reasonable penalty, do not expect the existence of an ideal leader or teacher as expected by society and the company. According to work, discipline is part of the performance factor. His research results show that work discipline has a positive effect on teacher work performance(Jaber \& Hammer, 2016). Given the importance of these problems, and to address the conditions above, research was carried out related to the Effect of Motivation and Work Discipline on the Performance of Primary School Teachers.

\section{Research Method}

The research conducted by the author on the Regional Teacher of East OKU Regency was carried out using the approach used in this research is a quantitative approach. The quantitative approach is used to determine the correlation between the independent variables and the dependent variable, namely the variables of motivation and work discipline on elementary school teachers' performance in East OKU Regency, South Sumatra. The type of research used is ex-post facto research, which aims to reveal the causal relationship between one subject and another subject under study by not manipulating because it only shows symptoms that exist or have occurred.

The research design is as shown below:

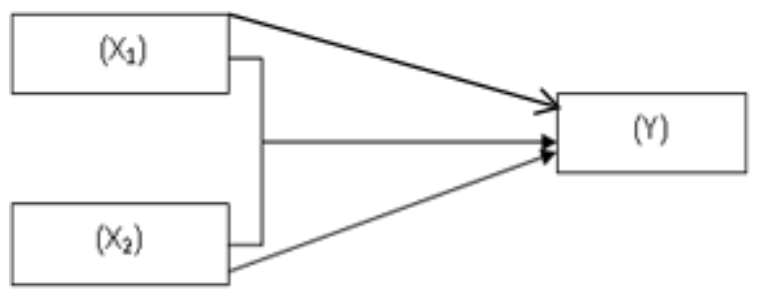

Figure 1. Regression Research Design

Multiple Linear

Information :

H1: Effect of X1 on Y alone H2: Effect of $\mathrm{X} 2$ on $\mathrm{Y}$ alone $\mathrm{H} 3$ : Effect of $\mathrm{X} 1$ and $\mathrm{X} 2$ on $\mathrm{Y}$ independently together

The research variables are as follows: Independent variable (independent variable)

Motivation (X1). The approach used in the teacher motivation variable (X1) to obtain data is by scoring each indicator of the existing dimensions, namely (a) need for achievement, (b) need for appreciation, (c) need for actualization. Self-work Discipline (X2) The approach used in the Work Discipline variable (X2) to obtain data in a way scoring each indicator of the existing dimensions, namely: (a) timeliness, (b) the ability to take advantage of and use opportunities (c) produce satisfying work, (d) follow the prescribed work methods, (e) 
have responsibility answer high. Dependent variable (dependent Variable) The approach used in the teacher performance variable "is there influence" to obtain data by scoring each dimension indicator of teacher performance which is manifested in the form of activities (a) planning the learning process, (b) implementing the learning process (c) evaluating the learning outcomes

This study's population were all elementary school teachers in East OKU Regency in the 2019/2020 lesson of 11,410 teachers. The sampling technique in this study used
Proportional Cluster Random Sampling based on the Central Limit Theorem, namely with a sample of 30 , there was an approach to the normal distribution of the population. The number of pieces in this study was 71 respondents. She was collecting research data using a questionnaire method/questionnaire, documentation, and observation.

\section{Result and Discus}

Instrument Validity Test Results

Table 1. Instrument Validity Test Results Teacher Welfare (X1)

\begin{tabular}{|c|c|c|c|}
\hline No Item & Correctedliem-Jotal Cornelation & Sig. & Keterangan \\
\hline $\mathrm{X}_{12}$ & 0.769 & 0.000 & Valid \\
\hline $\mathrm{X}_{4}=$ & 0.845 & 0.000 & Valid \\
\hline$X_{2,3}$ & 0.740 & 0.000 & Valid \\
\hline $\mathrm{X}_{\mathrm{l} \rightarrow}$ & 0.858 & 0.000 & Valid \\
\hline $\mathrm{X}_{\mathrm{l}-2}$ & 0.641 & 0.000 & Valid \\
\hline $\mathrm{X}_{1 \cdot 5}$ & 0.804 & 0.000 & Valid \\
\hline $\mathrm{X}_{2.7}$ & 0.654 & 0.000 & Valid \\
\hline $\mathrm{X}_{1,4}$ & 0.524 & 0.003 & Valid \\
\hline $\mathrm{X}_{1,9}$ & 0.628 & 0.000 & Valid \\
\hline $\mathrm{X}_{1-12}$ & 0.763 & 0.000 & Valid \\
\hline
\end{tabular}

Based on the table of values of the results of the motivation variable test results above, it is known that 15 out of 16 items of statements regarding the motivation variable are declared valid and can be used as a research tool because they have a calculated r-value greater than 0.468 .

Table 4. Instrument Validity Test Results Work Motivation (X2)

\begin{tabular}{|c|c|c|c|}
\hline No Soal & Corrected Ttem-Total Correlation & Sig. & Keterangan \\
\hline $\mathrm{X}_{.2}$ & 0.875 & 0.000 & Valid \\
\hline$X_{2}=$ & 0.880 & 0.000 & Vatid \\
\hline$X_{s-3}$ & 0.835 & 0.000 & Valid \\
\hline $\mathrm{X}_{-4}$ & 0.797 & 0.000 & Valid \\
\hline $\mathrm{X}_{\mathrm{2}-2}$ & 0.826 & 0.000 & Vatid \\
\hline $\mathrm{X}_{-5}$ & 0.911 & 0.000 & Vatid \\
\hline$X_{8-7}$ & 0.840 & 0.000 & Valid \\
\hline $\mathrm{X}_{\mathrm{S}-1}$ & 0.867 & 0.000 & Valid \\
\hline$X_{-\phi}$ & 0.891 & 0.000 & Valid \\
\hline$X_{*-10}$ & 0.628 & 0.000 & Valid \\
\hline
\end{tabular}

Based on the table of the results of the variability test of the Work Discipline variable above, it is known that 14 of the 16 statement items regarding the work discipline variable are declared valid and can be used as a research tool because they 
have a calculated r-value greater than 0.468 .

Reliability Test Results, the liability of a variable construct is adequate if the Cronbach Alpha value is> 0.60. The following is description of the reliability of each variable can be seen in Table 3 .
Table 3 shows that the internal construction liability value for each variable's alpha coefficient, Teacher Motivation (X1), and Work Discipline (X2), are declared reliable because they have a Cronbach value. Alpha is more significant than 0.60 . Thus the variable instruments of motivation and work discipline are reliable and can be used in this study.

Table 3. Variable Reliability Test Results

\begin{tabular}{|cccc|}
\hline Variabel & Apha & Apha & Kesimpulan \\
\hline Kesejahteraan Guru $\left(X_{1}\right)$ & 0.899 & 0.6 & Reliabel \\
Mbtivasi Guru $\left(\mathrm{X}_{3}\right)$ & 0.952 & 0.6 & Reliabel \\
\hline
\end{tabular}

Multiple Linear Regression Testing

The data analysis used in this research is multiple linear regression, which is used to determine whether there is an effect of
Teacher Welfare (X1), Work Motivation (X2), and Teacher Competence (X3) on Teacher Performance (Y).

Table 4 Results of Linear Regression Analysis Multiple

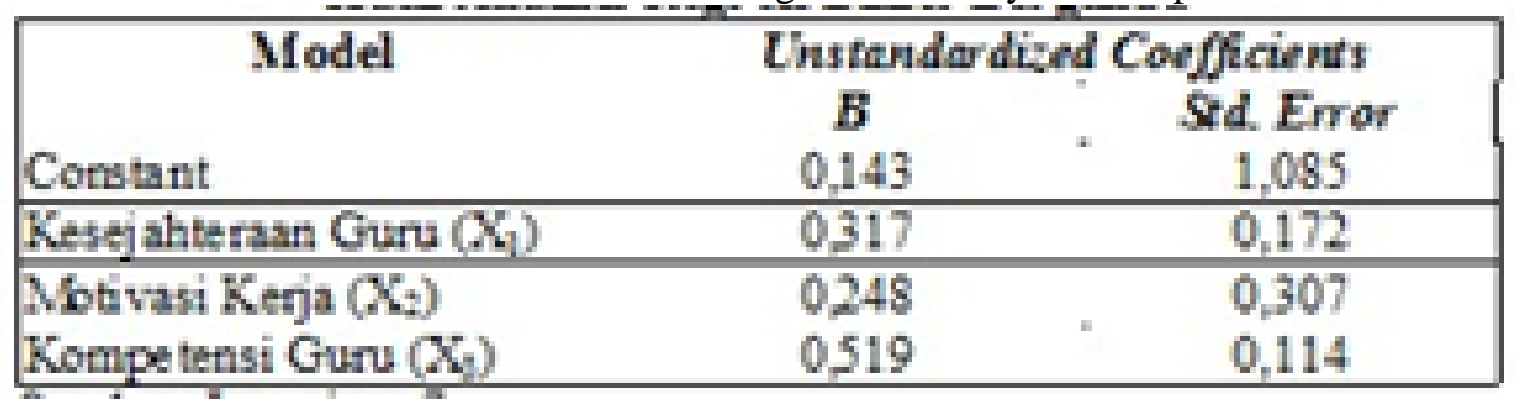

Based on the table above, a significant multiple linear regression equation is obtained as follows:

$=$ Teacher performance

$=$ Regression coefficient (0.143) (0.317) (0.248) (0.519)

From the regression equation above, the following conclusions can be drawn. First, the constant value $(\beta 0)$ will be equal to the Teacher Performance value (Y) of 0.143 if Teacher Welfare (X1), Work Motivation (X2), and Teacher Competence (X3) are constant or equal to zero. Second, the coefficient value of Teacher Welfare $(\beta 1)$ is 0.317 , indicating that if the Teacher Welfare variable (X1) increases by one unit, it will improve teacher performance by
0.317. It is assumed that the variables of work motivation and teacher competence are constant or equal to zero. Third, the coefficient value of Work Motivation ( $\beta 2$ ) is 0.248 , indicating that if the work motivation variable (X2) increases by one, it will result in a decrease in Teacher Performance of 0.248 , and it is assumed that the variables Teacher Welfare and Teacher Competence are constant or equal to zero. Fourth, the coefficient value of Teacher Competence $(\beta 3)$ is 0.519, indicating that if the Teacher Competency variable (X3) increases by one unit, it will improve Teacher Performance by 0.519 , assuming that the variables Teacher 
Welfare and Work Motivation are constant or have the same value. With zero.

Hypothesis Testing Results

Teacher welfare affects performance teacher. Teacher welfare is the gift of life's prosperity to the people who work in the educational environment, both in materials and spiritual. So, life is fulfilled, worthy, and better as reciprocal or remuneration from that responsibility be borne. The fulfillment of that welfare adequate for teachers will increase enthusiasm in their work so that awareness arises to develop and improve quality resources that exist in them. Based on the results of the analysis, it is known that there is none significant effect of teacher welfare (X1) against teacher performance $(\mathrm{Y})$ in a primary school in Ogan Komering Ulu Timur region. The conclusion drawn is the first hypothesis, "There is an influence between teacher welfare and the performance of elementary school teachers in West Sumba district, "it was stated rejected and not proven right. This finding contradicts experts' opinion, and the purpose of giving TPG is to increase teacher performance. This is if the majority of people assess a person's welfare in terms of how much income/salary received, but this is somewhat different from the primary school teacher in Ogan Komering Ulu Timur region who is assessing the interest is not only from how big income/salary received, but trust and the opportunity to become a teacher is a form of invaluable welfare price. Because having a profession as a person teaching staff in Ogan Komering Ulu Timur region can improve someone's social status. The high social quality of this teacher impact respect in society received.

Work motivation affects teacher performance. An explanation is a motivation present in someone to try to hold behavior change to meet their needs better. Encouragement is based on theoretical requirements Maslow, which consists of 5 needs (1) Physiological needs, (2) The need for security, (3) Love Needs, (4) Needs Award (5) Need for self-actualization) The results of the analysis show that work motivation is not affected by teacher performance. Based on this analysis results, the second hypothesis, "Yes The significant effect of work motivation on teacher performance primary school in Ogan Komering Ulu Timur region, "rejected and not proven the truth. This is because elementary school teachers in the Ogan Komering Ulu Timur region already have perfect work motivation. To improve its performance, it emphasizes the competency aspects possessed by elementary teachers. Teacher competence is a combination of the personal, scientific, technological, social, and spiritual abilities that make up the teaching profession's whole competency standards, including mastery of the material, understanding of learners, learning that educates personal development, and professionalism. Pedagogic competence is competency in ways to educate students. The manifestation of the bikini pedagogical competencies must be visible in the curriculum document (curriculum plan), containing a series of eye lessons, syllabus, teaching materials, and program strategies and learning activities; the scenario is arranged in a lesson plan. The results of the analysis show that teacher competence has a significant effect on teacher performance. Based on this analysis results, the conclusion is the third hypothesis: "there is a significant influence teacher competence on elementary school teachers' performance in the Ogan Komering Ulu Timur region accepted and proven to be true. Second, the variable shows a positive effect, or there is a unidirectional relationship, which means that it is higher the competence of the teacher will be even higher also the teacher's performance. Several factors influence teacher performance. Among them are teacher welfare, motivation work, and teacher competence. The analysis results show the variable Teacher Welfare (X1), Teacher Motivation (X2), and Teacher Competence (X3) simultaneously has a significant effect on Teacher 
Performance (Y). Based on this analysis results, the conclusion is the fourth hypothesis, "There is a mutual influence Among well-being teacher, Motivation work and competence Teacher to Performance teacher primary school in Ogan Komering Ulu Timur region, "be accepted and proven the truth.

\section{Conclusion}

Based on the data analysis results and the discussion in the previous chapter by using multiple regression analysis, the following conclusions can be drawn. First, there is an influence between motivation on elementary school teachers' performance in East OKU because teachers do not assess cause regarding the amount of salary/service fees received. Second, there is no influence between the discipline and the performance of elementary school teachers in East OKU. A high spirit of dedication is one of the factors that support teacher performance. Third, there is a joint influence between motivation and work discipline on elementary school teachers' performance in East OKU. To improve elementary school teachers' performance in East OKU, it is necessary to increase work motivation and teacher discipline.

\section{Reference}

[1] Allen, C., Nodelman, U., \& Zalta, E. N. (2002). The Stanford encyclopedia of philosophy a developed dynamic reference work. Metaphilosophy. https://doi.org/10.1111/14679973.00225

[2] Baumann, C., \& Krskova, H. (2016). School discipline, school uniforms, and academic performance. International Journal of Educational Management.

https://doi.org/10.1108/IJEM-09-

2015-0118

[3] Cui, W., Cao, G., Park, J. H., Ouyang, Q., \& Zhu, Y. (2013). Influence of indoor air temperature on human thermal comfort, motivation and performance. Building and Environment.

https://doi.org/10.1016/j.buildenv.20 13.06.012

[4] Gregory, A., Clawson, K., Davis, A., \& Gerewitz, J. (2016). The Promise of Restorative Practices to Transform Teacher-Student Relationships and Achieve Equity in School Discipline. Journal of Educational and Psychological Consultation. https://doi.org/10.1080/10474412.20 14.929950

[5] Gregory, A., \& Fergus, E. (2017). Social and emotional learning and equity in school discipline. Future of Children.

https://doi.org/10.1353/foc.2017.000 6

[6] Jaber, L. Z., \& Hammer, D. (2016). Engaging in Science: A Feeling for the Discipline. Journal of the Learning Sciences. https://doi.org/10.1080/10508406.20 15.1088441

[7] Kurniawan, Harry, H. (2019). Effect of Work Discipline and Work Environment on Employee Performance with Work Motivation as an Intervening Variable in Department of Tourism, Youth and Sport of Padang District. Archives of Business Research.

[8] Lusk, S., Paley, S., \& Spanyi, A. (2005). The Evolution of Business Process Management as a Professional Discipline. BP Trends.

[9] Markus, H. R., \& Kitayama, S. (2014). Culture and the self: Implications for cognition, emotion, and motivation. In College Student Development and Academic Life: Psychological, Intellectual, Social and Moral Issues. https://doi.org/10.1037//0033295x.98.2.224

[10] McMillan, H. S., Morris, M. L., \& Atchley, E. K. (2011). Constructs of the work/ life interface: A synthesis of 
the literature and introduction of the concept of work/life harmony. Human Resource Development Review. https://doi.org/10.1177/15344843103 84958

[11] Okello, D. R. O., \& Gilson, L. (2015). Exploring the influence of trust relationships on motivation in the health sector: A systematic review. Human Resources for Health. https://doi.org/10.1186/s12960-0150007-5

[12] Schmitter, P. C., Blecher, M., Schmitter, P. C., \& Blecher, M. (2020). The Discipline. In Politics as a Science. https://doi.org/10.4324/97810030321 44-4

[13] Skaalvik, E. M., \& Skaalvik, S. (2017). Dimensions of teacher burnout: relations with potential stressors at school. Social Psychology of Education. https://doi.org/10.1007/s11218-0179391-0

[14] Wood, A. J. (2018). Powerful Times: Flexible Discipline and Schedule Gifts at Work. Work, Employment and Society. https://doi.org/10.1177/09500170177 19839 